\title{
Symbolic Inversion in Death: Some Examples from the Old Testament and the Ancient Near Eastern world
}

Paul A Kruger

(University of Stellenbosch)

\section{ABSTRACT \\ Symbolic Inversion in Death: Some Examples from the Old Testament and the Ancient Near Eastern world}

Symbolic inversion is a widespread cultural phenomenon, the earliest examples of which can be traced back to the cultures of the ancient Near East. Symbolic inversion (mundus inversus) relates to those forms of expressive behaviour which invert commonly accepted social codes. One such area in the ancient Near Eastern and Old Testament world where this phenomenon manifested itself prominently is in the conception of life after death: life after death is often conceived as the direct inverse of what is customary in ordinary life.

\section{INTRODUCTION}

In c. $1950 \mathrm{BC}$ the Egyptian prophet Neferti saw a world which is characterised as follows: "I show thee the land topsy-turvy. The weak of arm is (now) the possessor of an arm. Men salute (respectfully) him who (formerly) saluted. I show thee the undermost on top ..." (Wilson 1969:445; for a more recent translation, cf. Shupak 2003) ${ }^{1}$.

The phenomenon of a "topsy-turvy world" (mundus inversus) is widespread in the literatures and cultures of the world. It refers to a place where everything is reversed in relation to the normal state of affairs. Babcock (1978:14) presents the following characterisation of this topos: "Symbolic inversion may be broadly defined as any act of expressive behavior which inverts, contradicts, abrogates, or in some fashion presents an alternative to commonly held cultural codes,

1 For a discussion of other literary passages where the same phenomenon occurs (e.g. "The Admonitions of Ipuwer", etc.), cf. Luria (1929). Old Testament texts that could be mentioned include Is 24:1-2 and Prov 30:21-23. Cf. also Schorch's recent attempt (2003) to interpret the Israelite marzeach feast along the same lines. For a literary appreciation of some of these "reversed sayings", cf. Strauss (2003:25-37). 
values, and norms be they linguistic, literary or artistic, religious, or social and political".

According to Kenner (1970) the first occurrences of this cultural phenomenon can be traced back to the ancient Near East. In Sumerian literature a classic example would be the dedication festivities of the Eninnu temple (Gudea Cylinder B), where it is imagined that masters/mistresses are on par with their slaves for a given time ${ }^{2}$. Similar feasts are attested under the Jews (Purim), the Greeks (Anthesteria) and the Romans (Saturnalia; see Stubbe 1988:199), and up to modern times in carnival-like celebrations, such as the German Fasching (Stolz 1997:94). The reversed world was likewise a popular fancy in art. In the sixteenth to the nineteenth centuries, for example, image-makers devoted a large share of their energy to depictions of a world turned upside down (Chartier 1988). It is to a similar "umgekehrte Welt" to which ancient Egyptian artists drew attention much earlier: a world in which a cat submits to mice and where a fox shepherds geese (see Brunner-Traut 1974:12f; Kenner 1967:12).

The principle of inversion is a universal faculty of human conception. In accordance with the "structuralist' line of thought" ... systems of classification are constructed according to the principle of binary opposition..." (Babcock 1978:27; see also Jebens 2000:323). So, for instance, certain groups could construct their idea of "other" groups through the strategy of "symbolic inversion". The "we" (one's own group) are accordingly endowed with every aspect that can be deemed as "cultivated", whilst the "other" is described in terms of direct opposite qualities (cf. Pongratz-Leisten 2001; Cohen 2001, with literature). A classic example from the ancient Near Eastern world would be the conception of a civilised Mesopotamian city dweller regarding his/her nomadic neighbour: the latter embodied in every respect "an inverse" world: "He is dressed in sheep skins; he lives in tents in wind and rain; he doesn't offer sacrifices. Armed (vagabond) in the steppe, he eats raw meat, lives his life without a home, and, when he dies, he is not buried according to proper rituals" (Van de Mieroop 1997:43). Herodotus, in his understanding of the institutions of foreign nations vis-à-vis

2 The text runs: "When his king entered into the temple, for seven days (xvii.20) the slave girl did become equal with her mistress; the slave did walk beside the master" (Cyl. B; translation by Averbeck 2003:432). 
the Egyptians, resorted to the same technique of inversion a number of times in his Histories (Hartog 1988:213); Tacitus employed a similar strategy in his depiction of the Jews (Bloch 2002), and this phenomenon persisted even in the ethnography of colonial writing ${ }^{3}$.

Another especially important form of symbolic inversion in many cultures in the world is to mark the boundaries between normal life and life after death: life after death is in many instances the direct reverse of ordinary life (Durkheim \& Mauss 1963:xxxix). Since the ritual of mourning is so closely associated with the phenomenon of death, it is not unexpected that mourning rites most often display similar reversals (Stubbe 1988). The aim of this short note is modest, viz. to collect a selection of examples from the Old Testament and ancient Near Eastern cultures which are expressive of the idea of inversion in the conception of life after death.

\section{SYMBOLIC INVERSION IN DEATH}

"Das Jenseits stellt die Inversion des Diesseits dar. Alles, was hier gilt, wird dort in sein Gegenteil verkehrt" (Janowski 2003:259) ${ }^{4}$. How this mundus inversus world is generally conceived, is illustrated by the anthropologist Lévy-Bruhl (1928:303ff) by way of a variety of ethnographic examples:

The world of the dead is the exact reverse of that of the living. Everything there is just the opposite ... There, for instance, the sun and the moon travel from west to east ... when the dead go downstairs, they go head first ... they go to market, but the market takes place at night ... They speak the same language as the living but every word has exactly the opposite meaning: ...

3 According to Kramer "Die Ethnographie des 19. Jahrhundert entwirft im Hinblick auf die 'eigene' Kultur die 'fremde' als 'verkehrte Welt"' (1981:77).

4 Berlejung (2001:469) calls this change in the nature of existence "ontological": "Der 'Reisende' betrat einen neuen 'Lebens'raum und einen neuen 'Lebens'abschnitt (d.h. Wechsel von Raum und Zeit), wurde von der Welt der Lebenden getrennt und der der Toten angegliedert ('gesellschaftliche Veränderung')". According to Stolz (1997:98): "Der Tod hebt nach fast allgemeiner Ansicht das Leben nicht einfach auf, sondern er transformiert es: der Verstorbene gelangt in einen Bereich mit charakteristisch anderen Daseinsbedingungen, als sie auf der Erde gelten" (my emphasis). See also Kramer (1981:58): "Im Land der Toten ist alles umgekehrt". See also Groneberg, who calls this realm an "Un-Ort" (1990:261). 
sweet means bitter, and bitter sweet. There, to stand up means to lie down, etc. (See also Stubbe 1988:200; Mühlmann 1961:614).

Translated into the life-world of an ancient Egyptian, such a state of existence would entail that categories of normal life are turned upside down:

... the damned have to walk upside down, eat their own excrement, and drink their own urine. Their hands are tied behind their backs, often around stakes; their heads and limbs are severed from their bodies and their flesh is cut off their bones; their hearts are taken out; their $b a$-souls are separated from their bodies, forever unable to return to them; and even their shadows are wiped out (Van Dijk 2001a:90).

Some, like the biblical Job, imagine the land of the dead as a place where an inverse order of social relations prevails, a form of existence he is longingly looking forward to: "There the prisoners are at ease together; they do not hear the voice of the taskmaster. Small and great are there, and the servant is free from his master" (Job 3:18-19). Others, like the king of Babylon (Is 14), was not that fortunate since a miserable fate awaited him in Sheol. Although he retains his status as king, he has to be content with a different order of things, implying a drastic degradation in quality of life: "Under you maggots are spread out and worms are your covering" (v.11). Death is indeed "... the great leveller of all", as Johnston aptly remarks (2002:76).

Various inversions mark the nature of the realm of death if compared with normal ordered life. With regard to the ancient Near East, the following inversions appear to be the most significant:

i) The netherworld is the realm "below" over against the world "above";

ii) It is a domain ruled by "darkness" instead of "light";

iii) The quality of normal life is replaced by all forms of misery;

iv) "Normal" beings become "inverted" in that sphere.

\subsection{The netherworld is the realm "below" versus the normal world "above"}

As in many other cultures of the world, the netherworld is conceived as the world "below" (Wächter 1993:903ff; Janowski 2003:257). 
The opening lines of the Sumerian version of Ishtar's 'Descent to the Netherworld call it "the great place below" (Heidel 1946:171). In Hittite thought this space is designated as the "lower land" (Haas 1995:2021). According to Sumerian conceptions, one "descends" to this realm (Katz 2003:16). The Hebrew Bible, likewise, refers to the Sheol "below" (מטה; Prov 15:24), the "lowest pit" (בור תחתית; Ps 88:7; Janowski 2001:11), the "deeps" (מצלות); Ps 88:7), the "world below" (מרזיץ תחתיז; Ezek 31:14, 16, 18), which all clearly stand in clear antithesis to the locality "above" (מעטל) and "heaven" (שמיםם) (Podella 1988:76). In Israelite thinking one equally "goes down" (רדי; Num 16:30, Jonah 2:7, Ps 22:30, etc.), or "descends" (נחת; Job 21:13) to Sheol, or "to the dust" (נחת על עפר; Job 17:16), or one "is debased" (שפל Hi; Is 57:9) into that domain (Wächter 1993:904). The inhabitants of this realm are consequently described as "those who went down to the pit" (רדיי בור"; Is 38:18, Ezek 26:20, Ps 28:1, Prov 1:12, etc.; Wächter 1993:904)5, or "those who went down to the dust" (רדי עפרי; Ps 22:30). Similarly, one "comes up" (עלד) from Sheol (1 Sam 2:6, 28:13, Ps 71:20, Job 7:9; Barth 1947:130; Podella 1988:76).

\subsection{The domain of darkness versus the normal world of light}

If the normal world is a realm where there is light in abundance, the netherworld is a dark place deprived of this essential element. This is an unvarying theme in most of the cultures of the ancient Near East. In the Descent of Ishtar to the Underworld (lines 3-9) the distinctive nature of this miserable place is described in the following terms:

The daughter of Sin was determined to go

To the dark house, dwelling of Erkalla's god,

To the house which those who enter cannot leave,

On the road where travelling is one-way only,

To the house where those who enter are deprived of light,

Where dust is their food, clay their bread,

They see no light, they dwell in darkness (Dalley 2003a:381). ${ }^{6}$

$5 \quad$ Similar terminology is attested in Ugaritic: $\operatorname{jrd}(m)(b) \operatorname{arc}$ (KTU 1.4 IV 8; VIII 8f; 1.5 II 4f; 1.114:22, etc.; see Gulde 2001:394). Cf. also the Akkadian combination warādu-elu, which signifies the "going down" to the netherworld and the "coming up" from there (Podella 1988:76).

6 Cf. also Gilgamesh VII 187-90 (George 1999:61) and Nergal and Ereshkigal iii 1-5 (Dalley 2003b:386), where the same lines are repeated; for 
The idea of darkness is likewise firmly rooted in the Old Testament. Often the netherworld is simply typified as "darkness" 88:13, Job 17:13, 18:18), or "deep darkness" (צלמות; Job 38:17), or "dark places" (מחשכים; Ps 88;7, 143:3), or in a more elaborate way

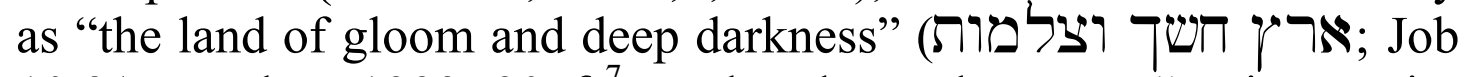
10:21; Wächter 1993: 907f) ${ }^{7}$, or the place where one "... in eternity will not see light" (Ps 49:20). It is interesting to note that the idea of darkness is not associated with the netherworld in the Ugaritic literature. An exception could, however, be KTU 1.4.VII 54-56, where reference is made to the "sons of darkness" who accompanied Mot (Gulde 2001:423).

\subsection{Quality of life on earth is replaced by misery}

"In the realm of the dead everything that gives colour to existence on earth, is wanting" (Zandee 1960:88). This conception manifested itself in different forms:

\subsubsection{Normal food is there replaced by contaminated food}

Mention was made above to a topos which recurs in ancient Near Eastern sources regarding the netherworld, viz. that the inhabitants have to survive on inedible food: "the house where those who enter are deprived of light, where dust is their food, clay their bread" (The Descent of Ishtar to the Underworld, lines 7-8). What is even much worse is that the denizens of the netherworld are destined to eat their own excrement and drink their own urine. Zandee (1960:73) explains this as a consequence of the fact that inhabitants of this realm have to walk upside down (see below). In Coffin Texts Spell

other Sumerian images of the netherworld as a dark place, see Katz (2003:223ff). See also the Hittite reference to the netherworld as the "dark/gloomy earth" (Haas 1995:2021), or "Haus der Finsternis" (Haas 1994:129). For references regarding the Egyptian literature, cf. Zandee (1960:88ff). For Zoroastrianism, cf. the remark by König (1964:104): "Es wird drei Kennzeichen der Hölle in den Gathas angeführt: schlechte Speise, Jammer und Wehgeschrei und Finsternis".

7 Cf. also the Akk. bit ekleti: "Haus der Finsternis" (Berlejung 2001:468).

8 Cf. also the reference in The Death of Urnammu: "Bitter is the food of the netherworld, brackish is the water of the netherworld" (line 82; Kramer 1967:118), and a passage in the Gilgamesh epic (XII:153) relating to the fate of the unburied dead: "He eats scrapings from the pot and crusts of bread thrown away in the street" (translation by George 1999:195, see also Podella 1988:82). 
661 it is said: "I do not eat filth. I do not drink urine. I do not go head down" (Zandee 1960:78)9.

Most apparently the Ugaritic literature bears testimony to a similar conception. In KTU 1.114:18-22 the god El is depicted in a state of drunkenness. The description evokes imagery which can be compared with the misery of those in the netherworld just referred to (Spronk 1986:198ff). The text runs:

He has fallen into his own dung and urine!

Ilu is like a dead man,

Ilu is like those who descend into the earth! ${ }^{10}$

\subsubsection{The freedom of ordinary life is replaced by captivity/inactivity}

This idea is expressed best by symbolising the netherworld as a prison (Barth 1947:78). Allusions to this conception are frequent in the Old Testament: mention is made of "gates" (שער שימ;) Is 38:10, Ps 9:14, 107:18, etc.), "bars" (בריחימ; Jonah 2:7) and "cords" (מרקשימ; Ps 18:6), which clearly evoke the idea of a prison (Johnston 2002:76; see also Tromp 1969:74-76) ${ }^{11}$. On other occasions the identification between the Sheol and a prison is even more direct: "Bring me out of the prison (מסגר) that I may give thanks to thy name" (Ps 142:8; translation by Tromp 1969:156). In a prophetic oracle (Is 14) the denizens of Sheol declare on the arrival of a newcomer (the king of Babylon): "You too are weak (חלה) as we are" (v. 10), whereas Ezek 32:21 notes that the deceased "have come down, they lie still (שכ)". Job 14:10 confirms in similar fashion: "When a man dies he is powerless", whilst Qohelet (9:10) in the same vein speculates: "... there is no work or thought or

9 For a similar fate befalling evildoers in the Hittite netherworld, cf. Goetze (1957:170). See also Xella (1980), who holds that $2 \mathrm{Kgs}$ 18:27 and Isa 36:12 should be viewed against the same background. In Dante's Inferno (Canto XVIII:112f) a corresponding conception of the underworld comes to the fore: "... and from where I stood I saw souls in the ditch plunged into excrement ..." (Musa 2003:235).

10 The translation is by De Moor (1987:136). For an updated bibliography on treatments of the text, cf Wiggins (1998:772ff).

11 The same image for the netherworld is also attested in Egyptian and the Mesopotamian cultures; cf. Barth (1947:78). 
knowledge or wisdom in Sheol, to which you are going" (see also Ps 88:5-6; Podella 1988:82). In view of this loss of energy, it is therefore quite conceivable why the dead are occasionally portrayed as those who have to "chirp (צכ) and mutter (הפד)" like birds (Is 8:19, 29:4; see also König 1964:188) ${ }^{12}$.

In Egypt the image of inactivity in the netherworld is, furthermore, closely connected with another characteristic of the underworld domain, viz. silence (see below). A wife lamenting at the bier of her husband presents the following dismal description: "How oppressing is going to the land of silence. The vigilant one becomes a sleeper. He who did not fall asleep during the night, now lies down tired all days (sic)" (Zandee 1960:94).

\subsubsection{Sound as the symbol of life is replaced by silence}

As seen above, the realm of the dead is the domain of silence. Apart from explicit references to this in Egypt (Zandee 1960:93f), the netherworld in Mesopotamia is likewise characterised as the place where "mächtige Stille"13 reigns. On his descent to the netherworld Enkidu is accordingly instructed by Gilgamesh (GEN 194): "Do not make a sound (resounding) in(to) the netherworld" (Podella 1989:81), since that would disturb the order of things there. Elsewhere in the same epic (Tablet VII:191-192) a similar notion is conveyed: "On the door [and bolt the dust lay thick,] on the House [of Dust was poured a deathly silence]" (George 1999:61).

Similarly, the netherworld is cast in the Old Testament in similar terms: it is a place of "silence" (דומה) preventing the believer from performing what is considered normal religious

12 The association of the deceased with birdlike features is also a frequent theme in Mesopotamian netherworld texts (Berlejung 2001:475ff). A passage in Nergal and Ereshkigal (Sultantepe ii A-C version, iii 4-7), for example, runs as follows: "[Bekleidet sind sie wie Vö]gel mit einem Flügelkleid, [kein Licht sehen sie], im Finsternis sitzen sie. [Zusammengedrängt in den Ecken], voll Jammer sind sie, [alle Tagen jammern] sie wie Tauben" (translation by Hutter $1985: 23)$. Berlejung deems this imagery very apt to juxtapose the dismal nature of existence of the inhabitants of the "Unterwelt" with those of the "Oberwelt": the "Bild der in Dunkelheit am Boden kauernden, eingesperrten und beständig gurrenden $=$ klagenden Vögel beschrieb ... das äusserst bedauerenswerte Dasein in der Unterwelt ..." (2001:479).

13 šiššu dannu, CAD Š III 127; see Berlejung (2001:469). 
behaviour, viz. to sing God's praise: "The dead do not praise God, nor do any that go down into silence" (דומה; Ps 115:17)

\subsubsection{Joy is replaced by joylessness}

That the netherworld is a gloomy place which allows no room for joy is a widespread theme in the ancient cultures. Jesus Sirach sums up this mood very tellingly when he summons all people, in the vein of Qohelet, to the joys of life over against the negative aspects of the netherworld: "Give and take, yea, indulge thy soul; for in Sheol there is no delight" (14:16, see Tromp 1969:189). This viewpoint is also echoed elsewhere in the ancient Near East. Two passages in particular demonstrate in a vivid way that the pleasures of ordinary life are reversed in death. In Inanna's Descent to the Netherworld the type of the behaviour expected of the inhabitants of that sphere becomes apparent through the norms that the demons of the underworld subscribed to:

296. The men who went toward Inanna,

297. They know no food, know no drink.

298. Eat no flour offering,

299. Drink no water libation.

300. Accept no nice gift.

301. They do not satiate a spouse's lap with pleasure, ${ }^{15}$

302. They do not kiss sweet children.

303. They tear the spouse from the man's lap,

304. They snatch the son from the man's knee.

305. They carry off the bride from her father-in-law's house (Katz 2003:267; see also Podella 1989:79).

14 Cf also Ps 31:18, 94:17; Barth (1947:79); (Heidel 1946:193) and Podella (1988:81). Apart from Ps 115, this topos of the "Verstummen der Lobpreisungen Gottes im Tod" occurs four more times in the Hebrew Bible: Isa 38:18f, Ps 6:6, 30:10, 88:11, also in Sirach 17:27ff and Bar 2:17 (König 1964:189; Janowski 2003:246f).

15 The Egyptian dead man also fears that he will not be able to satisfy his sexual desire (Zandee 1960:61). A spell in the Book of Going Forth by Day, which contains a dialogue between Osiris, the god of the dead with whom the deceased is identified, and Atum, the creator god, contains the following complaint: "O my lord, Atum, why is it that I have to travel to the district of silence, where there is no water and no air; which is so deep, so dark and so impenetrable? ... one cannot even have sex there!" (Van Dijk 2001b:26). 
A similar description is attested in the Gilgamesh Epic (Tablet 12), where Gilgamesh is described as crying over his playthings, the pukku and mekk $\hat{u}$, which fell through a hole into the netherworld. Enkidu volunteered to fetch them, but not before he is warned by Gilgamesh to behave according to a social code which stands in direct opposition to what people in the normal world are accustomed to:

185. Do not dress in a clean garment,

186. they would surely take it as the sign of a stranger!

187. Do not anoint yourself in sweet oil from the flask, ...

193. Do not wear sandals on your feet, ...

195. Do not kiss the wife you loved,

196. do not strike the wife you hated,

197. do not kiss the son you loved,

198. do not strike the son you hated (translation by George 1999:184; see also Podella 1989:81). ${ }^{16}$

For understandable religious reasons, the Old Testament, on the other hand, is very sketchy about the nature of the existence of the dead $^{17}$. One passage, however, where one gets a faint glimpse ("eine Soziologie", see Podella 1988:82) of how this inverse world is conceived, is Isaiah 14 , a passage already referred to above ${ }^{18}$. What befell the king of Babylon in that realm was not altogether pleasant: he is now relegated to a form of existence where he is deprived of what he was always used to, viz. the joyful sounds of the royal palace and a comfortable bed (v.11) ${ }^{19}$.

16 Another text which juxtaposes the quality of life in the netherworld with the nature existence in ordinary life is a passage in the Death of Urnammu: "His wife whom he no longer fondled(?) on his lap, his son whom he no longer raised on his knee" (Lines 150-151; Kramer 1967:119; see also Katz 2003:231).

17 Cf. Podella (1988:70f), who supplies some of the religious reasons for this state of affairs.

18 The only other passage describing in broad lines the fate befalling those in the underworld is Ezek 32.

19 This is in accordance with Urnammu's lamentation on his fate in the netherworld: "(Instead of) my throne whose attractiveness I had not fulfilled, in the dust of the pit they made me sit. (Instead of) my bed, the sleeping place, whose ... I had not fulfilled, in the steppe, of the faraway exterior, they made me lie" (lines 189-192; Katz 2003:226). Cf. also the description of the "Gegenwelt" kingdom of Mot (god of the netherworld) over against that of Baal (Gulde 


\subsection{5 "Normal" beings become "inverted" in this sphere}

With the conception referred to above that one has to eat one's own excrement goes a complex of other ideas which likewise reflect a reversal of normal existence. Instead of normal walking and breathing, the dead have to cope with an inverted order of life. In one of the coffin texts the wish is expressed not to "go upside down among the ones going upside down. I go on my feet like Nefertem. I smell air with my nose like Khonsu ... I see the road with my eyes" (Zandee 1960:76). Or "I do not eat ordure for you. I do not walk bent for you. I walk upright. My phallus is united with me. My anus is united with me. I eat with my mouth. I have motion with my anus" (Zandee 1960:76f).

The characteristic of the dead as being upside down is also found in the Jewish traditions (Smith 1978:157). According to one of the legends, the witch of Endor could easily recognise the identity of Saul who consulted her incognito for "in necromancy the peculiar rule holds good that, unless it is summoned by a king, a spirit raised from the dead appears head downward and feet in the air. Accordingly, when the figure of Samuel stood upright before them, the witch knew that the king was with her" (Ginsburg 1913:70). In the equivalent Septuagint version of 1 Samuel 28 (v. 14) it is

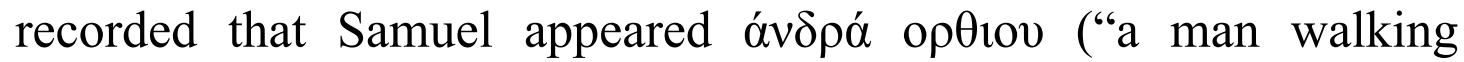

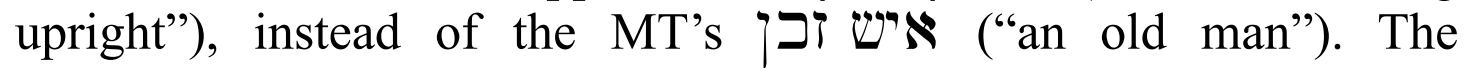
Septuagint reading very likely reflects "אכיש זכ" ("a prostrate man"; Ginsburg 1928:236), a rendering which Ehrlich (1968:264) associates "mit der ... rabbinischen Fabelei über heraufbeschworener Geister".

\section{Consulted literature}

Averbeck, R E 2003. The Cylinders of Gudea (2.155), in: Hallo, W H et al. (eds) 2003b, 417-433.

Babcock, B A 1978. The Reversible World. Symbolic Inversion in Art and Society. London: Cornell University Press.

Berlejung, A 2001. Tod und Leben nach den Vorstellungen der Israeliten, in: Janowski \& Ego (eds) 2001, 465-402.

Barth C 1947. Die Errettung vom Tode in den individuellen Klage- und Dankliedern des Alten Testamentes. Zollikon: Evangelischer Verlag.

2001:398ff; Podella 1988:79), and the Hittite name of the underworld: "as Dikkicht der Plage und Mühe" (Haas 1994:129). 
Bloch, R S 2002. Antike Vorstellungen vom Judentum. Der Judenexkurs des Tacitus im Rahmen der Griechisch-Römischen Ethnographie. Stuttgart: Franz Steiner.

Brunner-Traut, E 1974. Altägyptische Tiergeschichte und Fabel. Darmstadt: Wissenschaftliche Buchgesellschaft.

Chartier, R 1988. The World Turned Upside-down, in: Chartier, R (ed.). Cultural History. Between Practices and Representations. Translated by $\mathrm{L}$ G Cochrane. Oxford: Blackwell, 115-126.

Cohen, Y 2001. The Image of the "Other" and Hittite Historiography, in: Abusch, $\mathrm{T}$ et al. (eds). Historiography in the Cuneiform World (RAI XLVe). Bethesda, Maryland: CDL Press, 113-129.

Dalley, S 2003a. The Descent of Ishtar to the Underworld, in: Hallo, W H et al. (eds) 2003a, 381-384.

Dalley, S 2003b. Nergal and Erishkigal, in: Hallo, W H et al. (eds) 2003a, 384389.

De Moor, J C 1987. An Anthology of Religious Texts from Ugarit. Leiden: Brill.

Durkheim, E \& Mauss, M 1963 (1903). Primitive Classification. Translated by R Needham. London: Cohen \& West.

Ehrlich, A B 1968 (1910). Randglossen zur Hebräischen Bibel, Bd III. Hildesheim: Georg Olms.

George, A 1999. The Epic of Gilgamesh. New York: Barnes \& Noble.

Ginsburg, L 1913. The Legends of the Jews, IV. Philadelphia: The Jewish Publication Society of America.

Ginsburg, L 1928. The Legends of the Jews, VI. Philadelphia: The Jewish Publication Society of America.

Goetze, A 1957. Kleinasien. München: Beck’sche Verlagsbuchhandlung.

Groneberg, B 1990. Zu den mesopotamischen Unterweltsvorstellungen: Das Jenseits als Fortsetzung des Diesseits. Altorientalische Forschungen 17, 244-261.

Gulde, S 2001, Unterweltsvorstellungen in Ugarit, in: Janowski \& Ego (eds) 2001, 393-429.

Haas, V 1994. Geschichte der hethitischen Religion. Leiden: Brill.

-, 1995. Death and Afterlife in Hittite Thought, in: Sasson, J M (ed.). Civilizations of the Ancient Near East, Vol III. New York: Charles Scribner's \& Sons, 2021-2030.

Hallo, W H et al. (eds) 2003a. The Context of Scripture, Vol. I. Leiden: Brill.

-, et al (eds) 2003b. The Context of Scripture, Vol. II. Leiden: Brill.

Hartog, F 1988. The Mirror of Herodotus. Berkeley: University of California Press.

Heidel, A 1946. The Gilgamesh Epic and Old Testament Parallels. Chicago: 
University of Chicago Press.

Janowski, B \& Ego, B (eds) 2001. Das biblische Weltbild und seine altorientalische Kontexte. Tübingen: Mohr.

Janowski, B 2001. Die Toten loben YHWH nicht. Psalm 88 und das alttestamentliche Todesverständnis, in: Avemarie, F \& Lichtenberger, H (hrsg). Auferstehung - Resurrection. Tübingen: Mohr, 3-45.

-, 2003. Konfliktgespräche mit Gott. Eine Anthropologie der Psalmen. Neukirchen-Vluyn: Neukirchener Verlag.

Jebens, H 2000. Verkehrte Welt, in: Cancik, H et al. (hrsg). Handbuch religionswissenschaftlicher Grundbegriffe, Bd V. Stuttgart: Kohlhammer, 323-327.

Johnston, P S 2002. Shades of Sheol: Death and Afterlife in the Old Testament. Downers Grove: Intervarsity Press.

Katz, D 2003. The Image of the Netherworld in the Sumerian Sources. Bethesda. Maryland: CDL Press.

Kenner, H 1967. Das Phänomen der verkehrten Welt in der klassischen Antike. Forschungen und Fortschritte 41, 11-14.

-, 1970. Das Phänomen der verkehrten Welt in der griechisch-römischen Antike. Klagenfurt.

König, F 1964. Zarathustras Jenseitsvorstellungen und das Alte Testament. Wien: Herder.

Kramer, F 1981 (1977). Verkehrte Welten. Zur imaginären Ethnographie des 19. Jahrhunderts. 2. Auflage. Syndikat: Frankfurt.

Kramer, S N 1967. The Death of Urnammu and His Descent to the Underworld. JCS 21, 104-122.

Lévy-Bruhl, L 1928. The "Soul" of the Primitive. Translated by L A Clare. London: George Allen.

Luria, S 1929. Der Ersten werden die Letzten sein. Klio XXII, 405-431.

Mühlmann, W E 1961. Das Mythologem von der verkehrten Welt. Kölner Zeitschrift für Soziologie und Sozialpsychologie 13(4), 614-624.

Musa, M 2003. The Divine Comedy, Vol. 1: Inferno. Harmondsworth: Penguin Books.

Podella, T 1988. Grundzüge alttestamentlicher Jenseitsvorstellungen. BN 43, 70-89.

-, 1989. Sôm-Fasten: Kollektive Trauer um den verborgenen Gott im Alten Testament (AOAT 224). Neukirchen-Vluyn: Neukirchener Verlag.

Pongratz-Leisten, B 2001. The Other and the Enemy in the Mesopotamian Conception of the World, in: Whiting, R M (ed.). Mythology and Mythologies. Helsinki: The Neo-Assyrian Text Corpus Project, 195-231.

Schorch, S 2003. Die Propheten und die Karneval: Marzeach - Maioumas Maimuna. VT 53(3), 397-415. 
Shupak, N 2003. The Prophecies of Neferti, in: Hallo, W H et al. (eds) 2003a, 106-110.

Smith, J Z 1978. Map is not Territory. Chicago: University of Chicago Press.

Spronk, K 1986. Beatific Afterlife in Ancient Israel and in the Ancient Near East (AOAT 219). Neukirchen-Vluyn: Neukirchener Verlag.

Stolz, F 1997 (1988). Grundzüge der Religionswissenschaft (UTB 1980). Göttingen: Vandenhoeck \& Ruprecht.

Strauss, H 2003. Motiv und Strukturen von Umkehrungssprüchen in Ägypten und im Alten Testament. $Z A W$ 115, 25-37.

Stubbe, H 1988. Trauerverhalten und das Phänomen der verkehrten Welt. Zeitschrift für Ethnologie 113, 199-205.

Tromp, N J 1969. Primitive Conceptions of Death and the Netherworld in the Old Testament. Rome: Pontifical Biblical Institute.

Van de Mieroop, M 1997. The Ancient Mesopotamian City. Oxford: Clarendon Press.

Van Dijk, J 2001a. Hell, in: Redford, D B (ed). The Oxford Encyclopedia of Ancient Egypt, Vol 2. Oxford: Oxford University Press, 89-91.

-, 2001b. Paradise, in: Redford, D B (ed). The Oxford Encyclopedia of Ancient Egypt, Vol 3. Oxford: Oxford University Press, 25-27.

Wächter L 1993. שאור in: Botterweck, G J \& Ringgren, H (eds). Theologisches Wörterbuch zum Alten Testament, Vol. VII. Stuttgart: Kohlhammer, 901-910.

Wiggins, St A 1998. What's in a Name? Yarih at Ugarit. UF 30, 761-779.

Wilson, J A 1969. The Prophecy of Neferti, in: Pritchard, J B (ed). Ancient Near Eastern Texts Relating to the Old Testament. Princeton: Princeton University Press, 444-446.

Xella, P 1980. Sur la nourriture des morts, in: Alster, B (ed) 1980. Death in Mesopotamia. Papers read at the XXVIe Recontre assyriologique internationale. Copenhagen: Akademisk Forlag, 151-160.

Zandee, J 1960. Death as an Enemy According to Ancient Egyptian Conceptions. Leiden: Brill. 